\title{
TGF- $\beta 1$ induces HMGA1 expression: The role of HMGA1 in thyroid cancer proliferation and invasion
}

\author{
JING ZHONG $^{1 *}$, CHANG LIU $^{1,2 *}$, QING-HAI ZHANG ${ }^{1}$, LING CHEN $^{1}$, YING-YING SHEN ${ }^{1}$, \\ YA-JUN CHEN ${ }^{4}, \mathrm{XI} \mathrm{ZENG}^{5}, \mathrm{XU}-\mathrm{YU} \mathrm{ZU}^{1}$ and REN-XIAN CAO ${ }^{1,3}$ \\ ${ }^{1}$ Institute of Clinical Medicine, The First Affiliated Hospital of University of South China, Hengyang, Hunan 421001; \\ ${ }^{2}$ Department of Metabolism and Endocrinology, The First People's Hospital of Chenzhou, Chenzhou, Hunan 423000; \\ ${ }^{3}$ Department of Metabolism and Endocrinology, The First Affiliated Hospital of University of South China; \\ ${ }^{4}$ Department of Metabolism and Endocrinology, The Second Affiliated Hospital of University of South China; \\ ${ }^{5}$ Key Laboratory of Tumor Cellular and Molecular Pathology of the College of Hunan Province, \\ Cancer Research Institute, University of South China, Hengyang, Hunan 421001, P.R. China
}

Received December 16, 2016; Accepted March 30, 2017

DOI: 10.3892/ijo.2017.3958

\begin{abstract}
The role of transforming growth factor- $\beta 1$ (TGF- $\beta 1$ ) is complicated and plays a different role in the development of cancer. High mobility group A (HMGA1) participates in multiple cellular biology processes, and exerts important roles in the epithelial-mesenchymal transition (EMT). However, the correlation of TGF- $\beta 1$ and HMGA1 in cancer cells is not yet fully understood. In this study, we determined the effects of TGF- $\beta 1$ on HMGA1 expression in thyroid cancer cells and examined the role of HMGA1 in thyroid cancer progression. With real-time PCR and immunofluorescence staining, our study demonstrated that TGF- $\beta 1$ induced the expression of HMGA1 through phosphoinositide 3-kinase (PI3K) and the extracellular signal-related kinase (ERK) signaling in thyroid cancer cells. With luciferase reported assay, the HMGA1 promoter activity was activated by TGF- $\beta 1$ in the SW579 cells. Furthermore, lentivirus-mediated HMGA1 knockdown inhibits cellular oncogenic properties of thyroid cancer cells. Clinically, tissue microarray revealed that HMGA1 was expressed in thyroid carcinoma more than that in normal
\end{abstract}

Correspondence to: Professor Ren-Xian Cao or $\mathrm{Dr} \mathrm{Xu}-\mathrm{Yu} \mathrm{Zu}$, Institute of Clinical Medicine, The First Affiliated Hospital of University of South China, Hengyang, Hunan 421001, P.R. China

E-mail: caorenxian@hotmail.com

E-mail: zuxuyu0108@hotmail.com

*Contributed equally

Abbreviations: TGF- $\beta 1$, transforming growth factor- $\beta 1$; EMT, epithelial-mesenchymal transition; HMGA1, high mobility group A; PI3K, phosphoinositide 3-kinase; ERK, extracellular signal-related kinase; MMP-2, matrix metalloproteinase-2; DMSO, dimethyl sulfoxide; GFP, green fluorescent protein

Key words: TGF- $\beta 1$, HMGA1, proliferation, invasion, thyroid cancer thyroid tissues $(\mathrm{P}<0.001)$; expression of HMGA1 and MMP-2 was identified to be positively correlated $(\mathrm{P}=0.017)$. The present study established the first link between HMGA1 and TGF- $\beta 1$ in the regulation of thyroid cancer proliferation and invasion, and provided evidence for the pivotal role of HMGA1 in the progression of thyroid cancer, indicating HMGA1 to be potential biological marker for the diagnosis of thyroid cancer.

\section{Introduction}

The high mobility group A1 (HMGA1) belongs to superfamily of nonhistone chromatin-binding proteins and has two isoforms, HMGA1a and HMGA1b. HMGA1 is an architectural transcription factor and participates in multiple cellular biology processes, including transcriptional regulation, embryogenesis, transformation, cell cycle regulation, differentiation, viral integration, and DNA repair (1-3). Recently, HMGA1 was found to be associated with the occurrence and development of many malignant tumors, including breast (4), pancreas (5), lung (6), ovary (7), colon (8) and thyroid carcinomas (9). HMGA1 is also reported to be associated with high invasion and metastasis of the tumors. It may be a molecular prognostic marker of tumors (10).

Transforming growth factor- $\beta$ (TGF- $\beta$ ) is reported to exert an essential role on cell proliferation, differentiation, apoptosis, invasion, and cellular microenvironment (11-14). The role of TGF- $\beta$ in cancer occurrence and development has been extensively studied, and previous studies have shown that TGF- $\beta 1$ is a tumor suppressor in the early phase of tumor and it becomes a tumor-promoting factor during the late stages of cancer (15-17). The TGF- $\beta$ receptor is composed of type I TGF- $\beta$ receptors (T $\beta$ RI) and type II TGF- $\beta$ receptors (T $\beta$ RII), and both of them participate in classic TGF- $\beta 1$ signaling. With the presence of ligand binding, the type II receptors activate the type I receptors and recruit Smad2 and Smad3. Activated Smad2 and Smad3 bind to Smad4, and transfer into the nucleus to regulate gene expression (18). In addition to the classic TGF- $\beta 1 /$ Smad pathway, TGF- $\beta 1$ can also be activated 
by activating non-Smad pathways, such as the phosphatidylinositol-3 kinase (PI3K), extracellular signal-regulated kinase [ERK, mitogen-activated protein kinase (MAPK)], c-Jun NH2-terminal kinase (JNK) and p38 MAPK pathways and Rho GTPases (19). TGF- $\beta 1$ is generally considered to be a necessary promoter for epithelial-mesenchymal transition (EMT) and EMT is considered to be an important initiator for tumor invasive behavior during cancer progression (20-23).

We aimed to determine the effects of TGF- $\beta 1$ on the expression of HMGA1 in thyroid cancer cells. To our knowledge, the present study provides the first link between TGF- $\beta 1$ and HMGA1 in thyroid cancer cells, and revealed that PI3K and ERK signaling are involved in the TGF- $\beta 1$-induced HMGA1 expression. In addition, matrix metalloproteinase-2 (MMP-2) was also found to be correlated with the invasion induced by HMGA1 in thyroid cancer cells. This study also provided further evidence for the pivotal role of HMGA1 in the progress of thyroid cancer.

\section{Materials and methods}

Cell culture. Human thyroid cancer cell line TPC1 and SW579 were purchased from American Type Culture Collection (USA). TPC1 cells were cultured in DMEM medium with $10 \%$ fetal bovine serum at $37^{\circ} \mathrm{C}$ in a humidified atmosphere containing $5 \% \mathrm{CO}_{2}$. SW579 cells were cultured in L15 medium supplemented with $10 \%$ fetal bovine serum at $37^{\circ} \mathrm{C}$ in a humidified atmosphere without $\mathrm{CO}_{2}$.

Ethics approval and consent to participate. The ethics approval and consent for the use of human tissue was confirmed by the ethics committee of the First Affiliated Hospital of University of South China.

Reagents. The ERK inhibitor PD98059 $(20 \mu \mathrm{M})$ and U0126 (25 $\mu \mathrm{M})$, PI3K inhibitors wortmannin (100 $\mathrm{nM})$ were purchased from Calbiochem Corp. (San Diego, CA, USA). while wortmannin, PD98059 and U0126 were dissolved in $0.1 \%$ (vol/vol) dimethyl sulfoxide (DMSO).

Transient transfection and luciferase activity assay. Transient gene delivery was carried out as described previously (24). A luciferase assay kit (Promega) was used to measure the reporter activity according to the manufacturer's instructions. SW579 cells were cultured in serum-free medium for $12 \mathrm{~h}$ in a 12-well plate. The cells were transfected with the HMGA1 promoter vector containing luciferase or with the control vector, pGL4.1 and after $6 \mathrm{~h}$ of transfection, the cells were treated with or without TGF- $\beta 1$ at the indicated concentration for $12 \mathrm{~h}$. Luciferase activity was normalized by using a Renilla luciferase internal control.

Immunofluorescence. SW579 cells were seeded on a round glass cover placed into a 6 -well microtiter plate. The cells treated with TGF- $\beta 1$ at the indicated concentration were fixed with $4 \%$ paraformaldehyde-PBS for $15 \mathrm{~min}$ at room temperature, washed with PBS twice and then permeabilized by incubation with $0.1 \%$ Triton $\mathrm{X}-100$ for $5 \mathrm{~min}$. The cells were washed twice with PBS again and stained with anti-HMGA1 (1:100; ab4078, Abcam) antibody for $2 \mathrm{~h}$ at room tempera- ture. After washing with PBS, each sample was incubated with FITC-conjugated secondary antibodies (Boster, Wuhan, China) for $1 \mathrm{~h}$. The samples were washed with PBS twice and incubated with 4',6-diamidino-2-phenylindole (DAPI) $15 \mathrm{~min}$. The samples were analyzed under a fluorescence microscope (Olympus, Tokyo, Japan).

RNA isolation and real-time RT-PCR. The SW579 were treated with TGF- $\beta 1(0,1,2,5$ and $10 \mathrm{ng} / \mathrm{ml})$ for $12 \mathrm{~h}$ or wortmannin (100 nM), PD98059 $(20 \mu \mathrm{M})$ and U0126 $(25 \mu \mathrm{M})$, and maintained in culture medium for $2 \mathrm{~h}$. Total RNA of SW579 cells was extracted using TRIzol reagent (Invitrogen) and was reverse transcribed into cDNA using the first-strand synthesis kit (Gibco-BRL, Carlsbad, CA, USA). The mRNAs of HMGA1 and GAPDH were amplified with a denaturation step $\left(95^{\circ} \mathrm{C}\right.$ for $\left.1 \mathrm{~min}\right)$, followed by 35 cycles of denaturation $\left(95^{\circ} \mathrm{C}\right.$ for $\left.10 \mathrm{sec}\right)$, annealing and extension $\left(60^{\circ} \mathrm{C}\right.$ for $\left.20 \mathrm{sec}\right)$. Results from 3 separate experiments were analyzed, and GAPDH as a reference.

Construction and screening of lentiviral vectors harboring HMGAl-specific siRNA. The siRNA sequences targeting to human HMGA1 gene (GenBank accession no. NM_145901) were selected: Target1: ACTCCAGGAAGGAAACCAA; Target2: AGCGAAGTGCCAACACCTA; and Target3: GCT ACCAGCGCCAAATGTT. Three pairs of complementary oligonucleotides were designed, and cloned into a lentivirusbased vector (pGCSIL-GFP, Genechem, Shanghai, China). Lentiviral particles were prepared as previously described (25).

Three lentiviral constructs carrying siRNAs were used to infect SW579 cells at a multiplicity of infection (MOI) of 20 (low MOI) and 40 (high MOI). Three days after infection, GFP expression was measured to calculate the infection efficiency. Five days after infection, cells were harvested for test HMGA1 knockdown efficiency with real-time RT-PCR, and the siRNA with the highest knockdown efficiency was used for subsequent experiments.

Cell proliferation and colony formation assays. Cells were seeded in 96-well plates (2,000 cells/well) and counted using an automated cell counter (Nexcelom Bioscience, Lawrence, MA, USA). For colony formation assay, cells were seeded in 12-well plates (400 cells/well) and cultured for 8 days. Each experiment was repeated in triplicate and performed at least twice.

Cell cycle analysis by flow cytometry. The transfected cells were seeded in 6 -well plates at $2 \times 10^{5} /$ well. After the indicated treatments, the cells were harvested by trypsinization and washed with PBS and fixed overnight in ice-cold $75 \%$ ethanol at $-20^{\circ} \mathrm{C}$. The immobilized cells were washed, and dissolved in RNAse, followed by incubation at $37^{\circ} \mathrm{C}$ for $30 \mathrm{~min}$. Next, cells were stained with propidium iodide (PI) for $30 \mathrm{~min}$. The DNA content of the cells was measured using a BD Accuri C6 flow cytometer (BD Biosciences).

Cell invasion assays. The transfected cells (10,000 cells/well) were resuspended in serum-free medium and seeded in the upper chamber of a 24-well Matrigel ${ }^{\mathrm{TM}}$ Invasion Chamber (BD Biosciences, San Diego, CA, USA) coated with Matrigel. Cell invasion was calculated as the percentage of total cells 
A

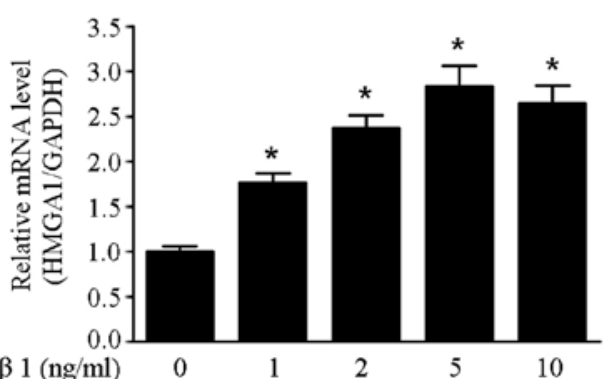

B

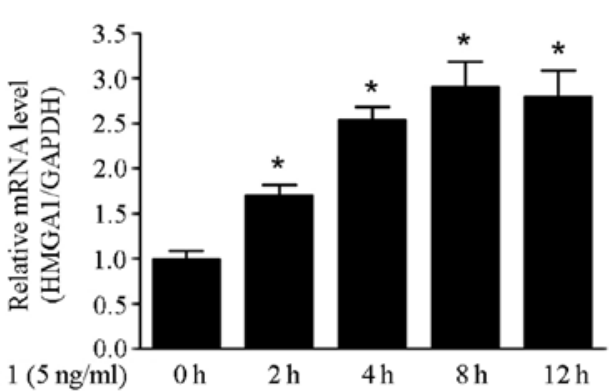

C
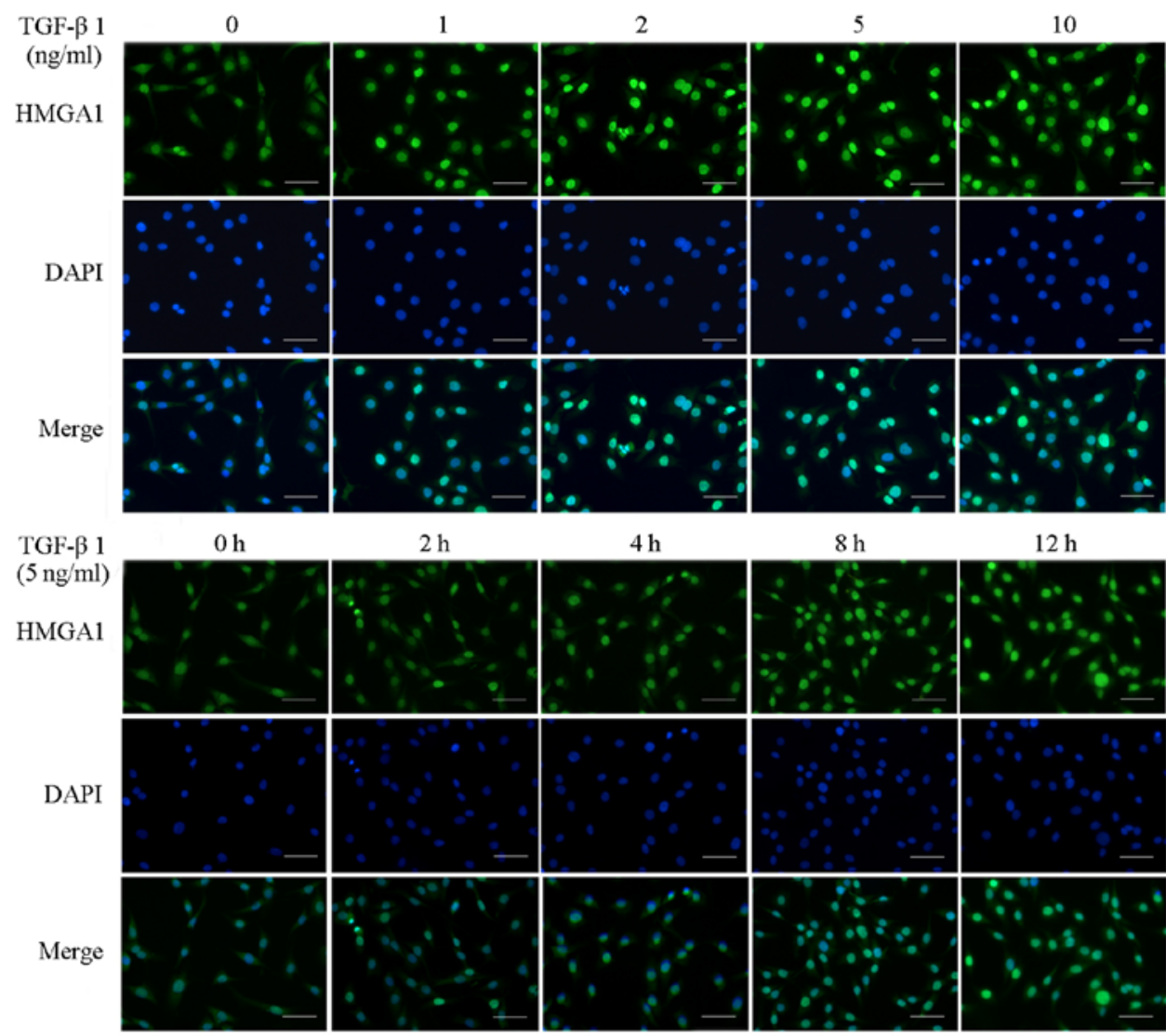

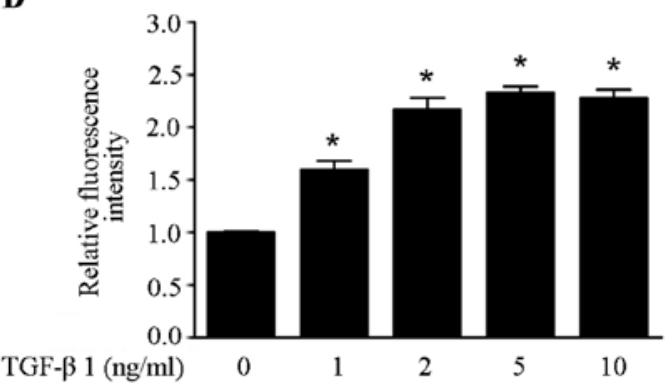

$\mathbf{E}$

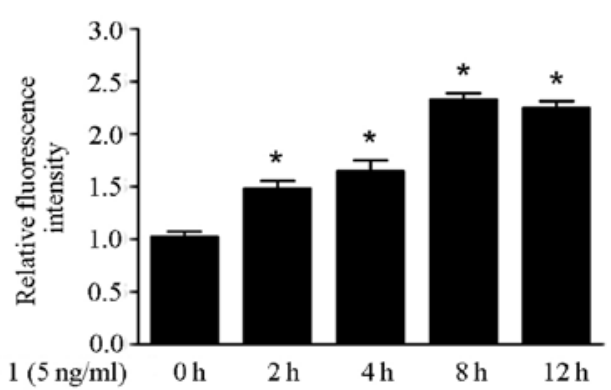

Figure 1. TGF- $\beta 1$ enhances HMGA1 expression in SW579 cells. (A) Real-time PCR analysis of HMGA1 expression induced in SW579 cells by treatment with various concentrations of TGF- $\beta 1$ for $8 \mathrm{~h}$. (B) Real-time PCR analysis of HMGA1 expression induced by treatment with $5 \mathrm{ng} / \mathrm{ml}$ of TGF- $\beta 1$ for the specified time. (C-E) Immunofluorescence staining of HMGA1 expression induced by treatment with different concentrations of TGF- $\beta 1$ for $8 \mathrm{~h}$ or with $5 \mathrm{ng} / \mathrm{ml}$ of TGF- $\beta 1$ for the specified time in SW579 cells. Fluorescence were gathered and analyzed with a fluorescence microscope (Olympus). ${ }^{*}<0.05$, compared to the group not treated with TGF- $\beta 1$. Scale bar, $50 \mu \mathrm{m}$.

that had invaded the bottom chamber containing complete medium with serum.

Scratch-wound assays. Cells were transiently transfected and grown to confluence. The central linear wound area was carefully generated by scratching the cell monolayer with a sterile
200- $\mu 1$ pipette tip, and images were taken after $24 \mathrm{~h}$. Bars represent as the average percentage of wound closure relative to the initial wound area.

Western blot analysis. The lysates of cell or tissue were lysed for $30 \mathrm{~min}$ on ice. Soluble proteins $(30 \mu \mathrm{g})$ were probed with 
A

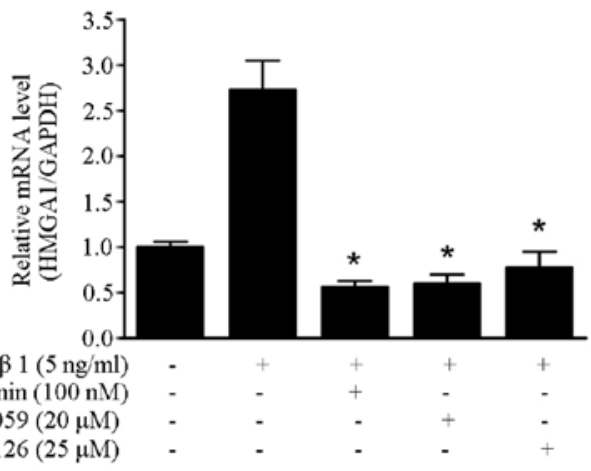

C

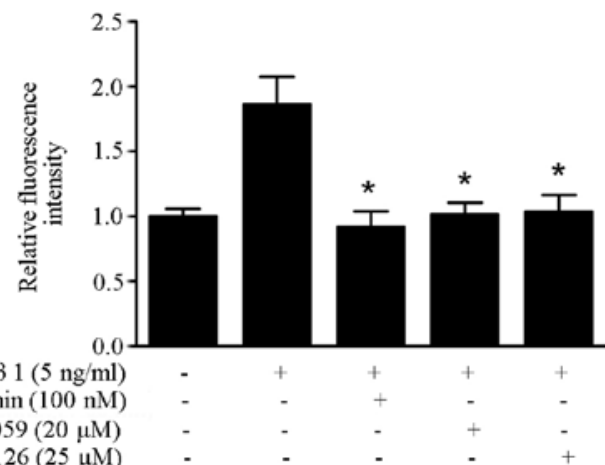

B

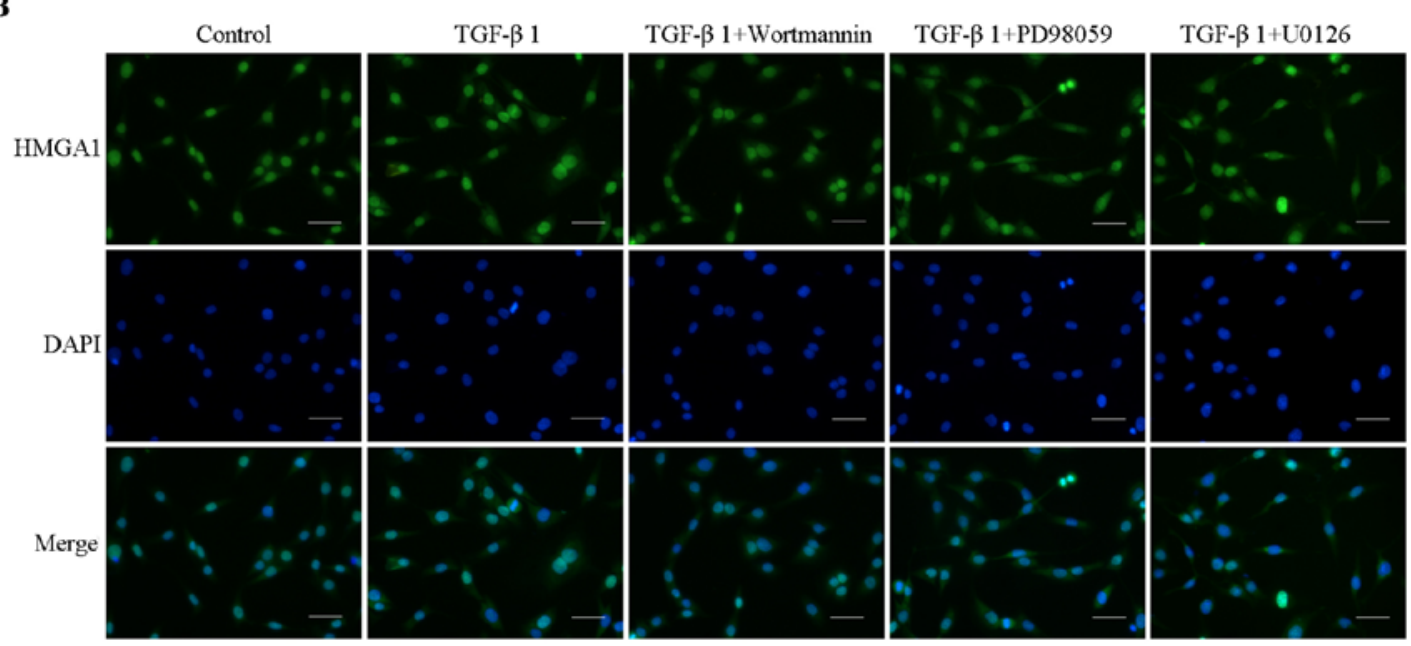

Figure 2. TGF- $\beta 1$ induces HMGA1 expression through PI3K signaling and ERK signaling in SW579 cells. (A) The effects of wortmannin, PD98059 and U0126 on the mRNA expression of HMGA1 induced by treatment with $5 \mathrm{ng} / \mathrm{ml}$ of TGF- $\beta 1$ in SW579 cells. (B and C) The effects of wortmannin, PD98059 and U0126 on the expression of HMGA1 induced by treatment $5 \mathrm{ng} / \mathrm{ml}$ with TGF- $\beta 1$ in SW579 cells. Fluorescence were gathered and analyzed with a fluorescence microscope (Olympus). "P<0.05, compared to the group treated with TGF- $\beta 1$. Scale bar, $50 \mu \mathrm{m}$.

anti-HMGA1 (1:1,000; ab4078, Abcam), anti-E-cadherin antibodies (1:500; \#3195, CST) and MMP-2 (1:500; ab37150, Abcam). Loading variations were normalized with GAPDH, and was identified with anti-GAPDH monoclonal Ab.

Tissue microarray and immunohistochemical analysis. IHC staining of the tissue microarray (TH8010a, US Biomax) was performed as detailed in our previous studies (26). The rabbit polyclonal HMGA1 antibody (1:150; ab4078, Abcam) and MMP-2 antibody (1:100; ab37150, Abcam) were used.

Statistical analysis. All experiments were performed in triplicate and the results were expressed as mean \pm SD. Statistical analysis was performed using SPSS, version 13.0 (SPSS, Inc., Chicago, IL, USA). Non-parametrically two-tailed Mann-Whitney U test was used to test statistical association between clinicopathological and molecular parameters. P-values $<0.05$ were considered significant. Spearman's rank correlation coefficients were used to assess the correlation of HMGA1 and MMP-2 expression with clinicopathological parameters.

\section{Results}

HMGA1 expression is increased by TGF- $\beta 1$ in thyroid cancer SW579 cells. It has been shown that TGF- $\beta 1$ could stimulate the invasion and metastasis of cancer cells. TGF- $\beta 1$ has high expression in most malignant tumors, and is a necessary factor for cancer initiation and development (27). In this study, we investigated the effects of TGF- $\beta 1$ on the expression of HMGA1 in thyroid cancer SW579 cell line. As shown in Fig. 1A and B, TGF- $\beta 1$ elevated the HMGA1 mRNA level in a dose- and time-dependent manner in SW579 cells. Immunofluorescence assay revealed that the HMGA1 expression was also enhanced in a dose- and time-dependent manner by TGF- $\beta 1$ in SW579 cells (Fig. 1C-E). These data indicate that TGF- $\beta 1$ is a positive regulator of HMGA1 expression in thyroid cancer cells.

TGF- $\beta 1$ upregulates HMGA1 expression through the PI3K/Akt and ERK pathway. Previous studies have shown that PI3K/Akt and MAPK were involved in the cellular and molecular events of TGF- $\beta 1$ signaling $(28,29)$. The inhibitors of PI3K/Akt and ERK pathway wortmannin, PD98059 and U0126 were utilized to elucidate the underlying molecular mechanism of TGF- $\beta 1$-induced HMGA1 expression. As shown in Fig. 2A, TGF- $\beta 1$-induced HMGA1 mRNA transcription was abrogated by treatment with wortmannin, PD98059 and U0126 in SW579 cells. Immunofluorescence staining showed that wortmannin, PD98059 and U0126 could block the TGF- $\beta 1$ induced HMGA1 expression in SW579 cells (Fig. 2B and C). These results suggest that PI3K/Akt and ERK pathway are 
A

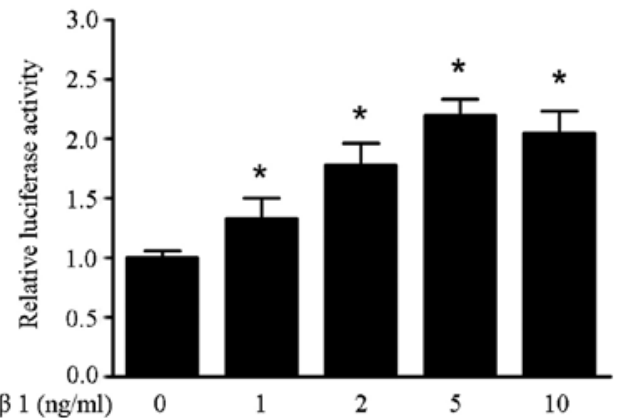

B

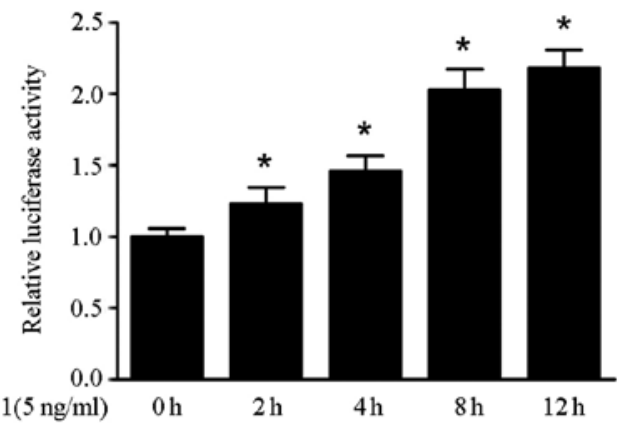

C

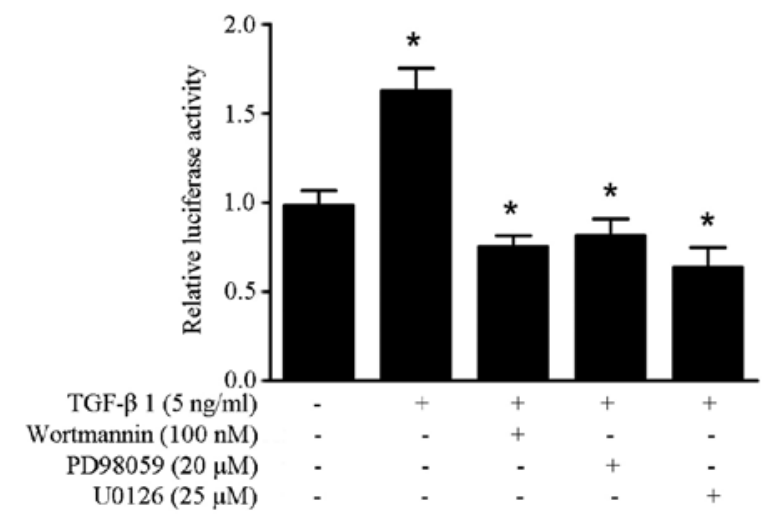

Figure 3. TGF- $\beta 1$ enhances the promoter activity of HMGA1 in SW579 cells. (A) The effects of TGF- $\beta 1$ on HMGA1 promoter activity. HMGA1 promoter, control vectors or pGL4.1 vectors were transfected into SW579 cells, and treated with the indicated concentrations of TGF- $\beta 1$. (B) The effects of $5 \mathrm{ng} / \mathrm{ml}$ TGF- $\beta 1$ on HMGA1 promoter activity. HMGA1 promoter, control vectors or pGL4.1 vectors were transfected into SW579 cells, and treated with $5 \mathrm{ng} / \mathrm{ml}$ TGF- $\beta 1$ for the indicated time. (C) The effects of $5 \mathrm{ng} / \mathrm{ml}$ TGF- $\beta 1$ on HMGA1 promoter activity with wortmannin (100 nM), PD98059 (20 $\mu \mathrm{M})$ or U0126 $(25 \mu \mathrm{M})$ in SW579 cells, "P $<0.05$. Luciferase activity was normalized by using a Renilla luciferase internal control. Each experiment was repeated in triplicate and performed at least twice.

involved in TGF- $\beta 1$-induced HMGA1 expression in thyroid cancer cells.

TGF- $\beta 1$ upregulates HMGAl expression by enhancing the promoter activity of HMGAl in thyroid cancer cells. To further elucidate the molecular mechanism of TGF- $\beta 1$ induced HMGA1 expression, we obtained the HMGAl promoter sequence from the SW579 cells. It was found that TGF- $\beta 1$ could enhance the promoter activity of HMGA1 in a dose- and time-manner in the SW579 cells (Fig. 3A and B). As shown in Fig. $3 \mathrm{C}$, the increased promoter activity of $H M G A l$ induced by TGF- $\beta 1$ was abrogated by treatment with wortmannin, PD98059 and U0126 in SW579 cells. These data suggest that TGF- $\beta 1$ upregulates HMGA1 expression by enhancing the promoter activity of $H M G A 1$ in thyroid cancer cells.

Lentivirus-mediated HMGA1 knockdown inhibits cell growth in the (least)non-invasive cell line in vitro. We have reported that siRNA-mediated HMGA1 silencing in thyroid cancer cells could inhibit the cellular oncogenic characteristics (30). To determine whether lentivirus-mediated HMGA1 knockdown have effect on the cellular oncogenic properties of thyroid cancer, three lentivirus-mediated shRNA targeting HMGA1 gene constructs with different shRNAs (KD1, KD2 and KD3) were used to infect thyroid cancer TPC1 and SW579 cells. The infection efficiencies of these lentiviral vectors were $>90 \%$ (Fig. 4A and B). Real-time RT-PCR assay showed that all three constructs, used at high or low MOI, significantly downregulated HMGA1 expression in TPC1 cells (Fig. 4C). The highest knockdown efficiency was obtained by using KD3 (low MOI, $81 \%$ relative to the NC group; high MOI, 82\%), which was named as HMGA1/GV248RNAi-LV-3.

HMGA1/GV248RNAi-LV-3 was transfected into thyroid cancer TPC1 cells and SW579 cells. As shown in Fig. 5A, TPC1 cell proliferation was significantly inhibited in the HMGA1 knockdown group compared with the control group and the $\mathrm{NC}$ group at day four $(\mathrm{P}<0.05)$, whereas the proliferate capacity of SW579 cells showed no significant difference in the three groups (data not shown). It was found that the number of formed colonies by lentivirus-mediated knockdown of HMGA1 was significantly decreased compared to those in control and NC group (Fig. 5B, $\mathrm{P}<0.01$ ). The number of formed colonies of SW579 cells have no significant different in the three groups (data not shown). In additions, cell cycle assay analysis showed that the cell populations in the $G_{0}-G_{1}$ and $S$ phases of TPC1 cells with HMGA1 knockdown markedly increased (Fig. $5 \mathrm{C}, \mathrm{P}<0.01$ and $\mathrm{P}<0.001$ ) and the population of $\mathrm{G}_{2}-\mathrm{M}$ phases significantly decreased (Fig. $5 \mathrm{C}, \mathrm{P}<0.001$ ). Those results indicated that HMGA1 knockdown inhibits the proliferation capacity in the (least)non-invasive thyroid cancer TPC1 cells, but has no obvious effect on invasive thyroid cancer SW579 cells.

Lentivirus-mediated HMGA1 knockdown inhibits the invasion and migration in SW579 cells. In order to determine whether lentivirus-mediated HMGA1 knockdown could affect 
A a

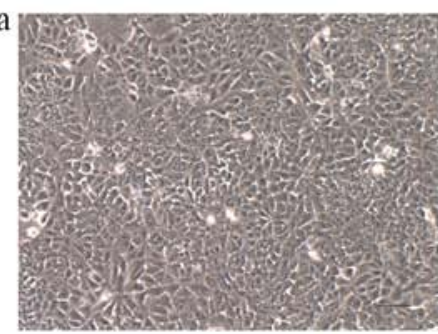

$\mathrm{b}$

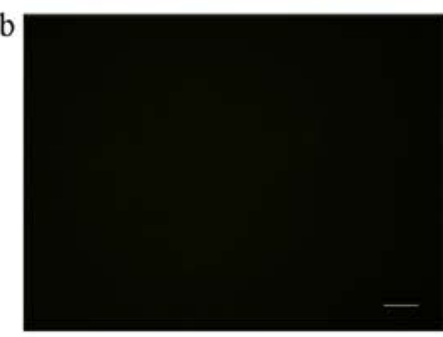

B
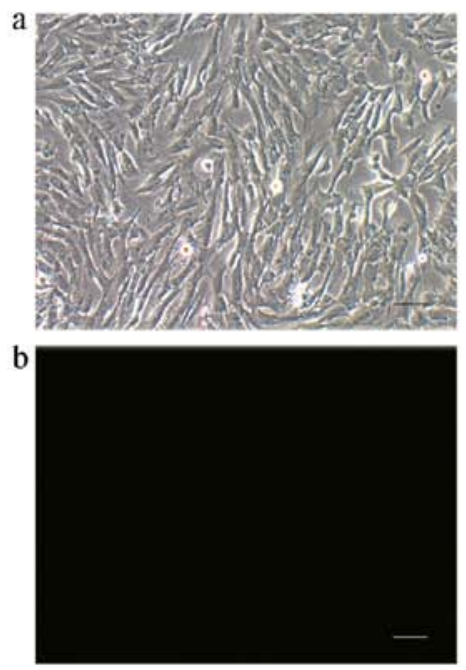

C

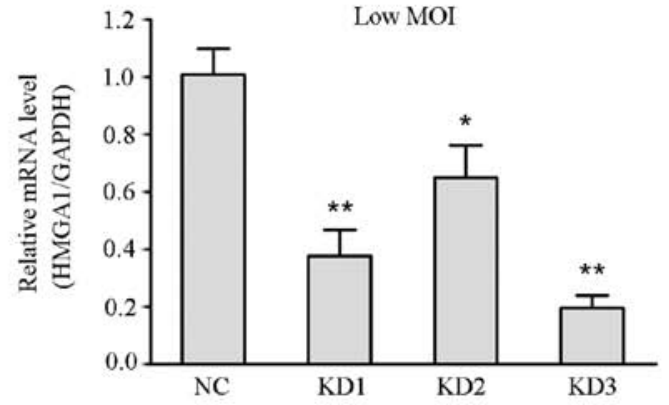

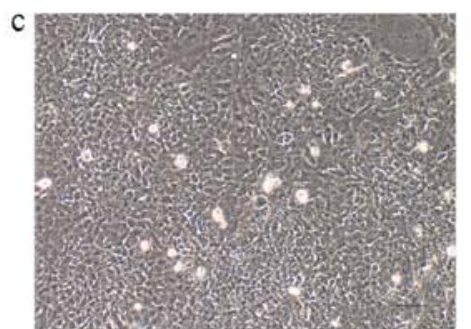
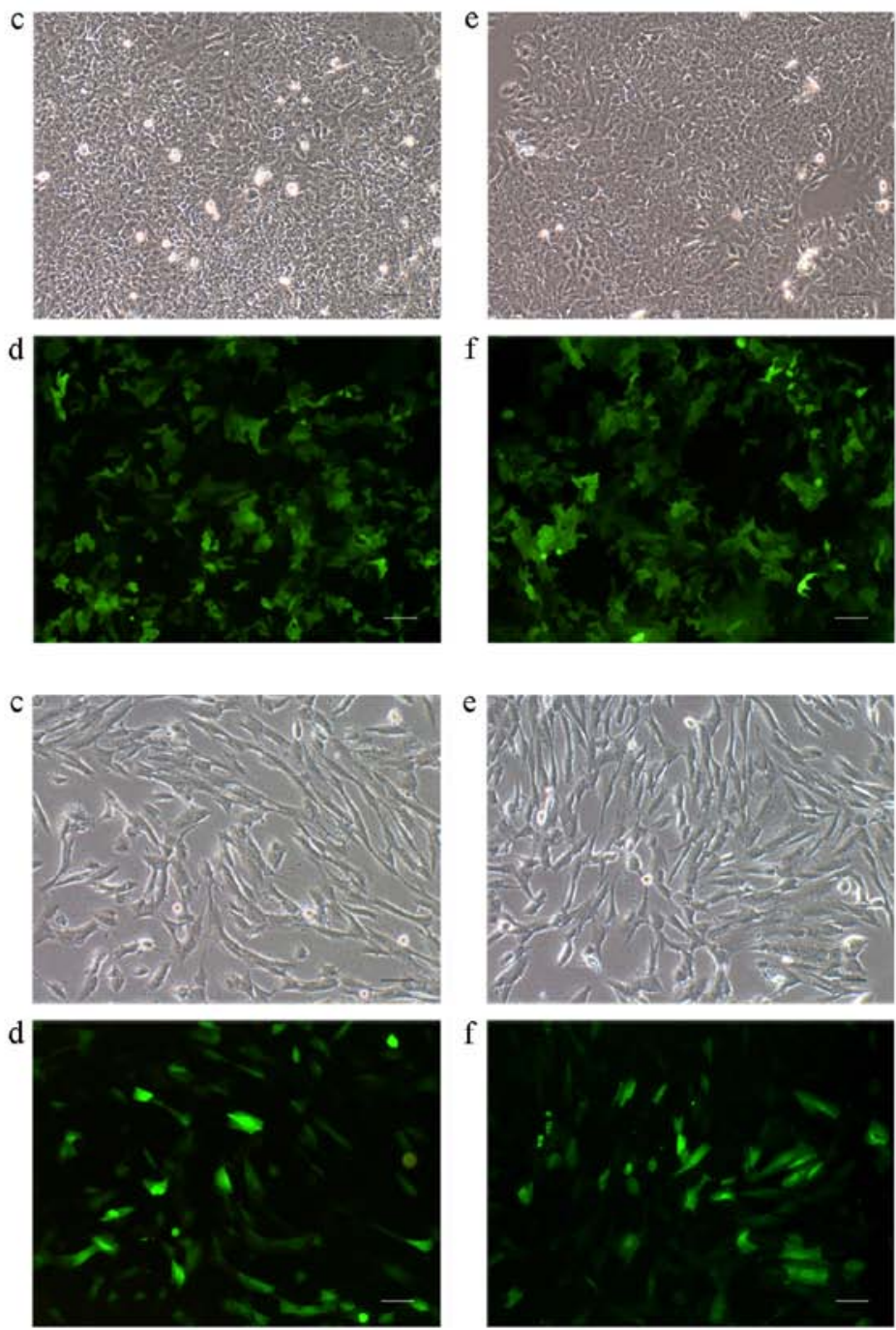

High MOI

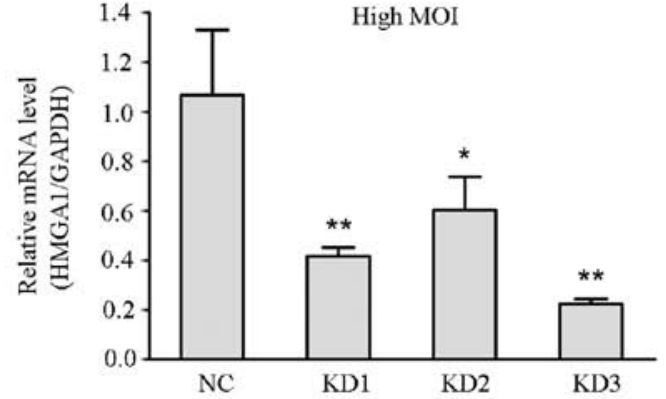

Figure 4. Identification of the lentiviral vector with the highest knockdown efficiency. (A) Fluorescence microscopy was used to observe the infection efficiency of different lentiviral vectors in TPC1 cells (magnification, $\mathrm{x} 100$ ). a, TPC1 cells without lentiviral infection in the optical microscope (Con group); b, TPC1 cells of Con group in the fluorescence microscope; c, TPC1 cells were infected with negative lentivirus NC/GV248 RNAi-LV (NC group) in the optical microscope; $\mathrm{d}$, TPC1 cells of NC group in the fluorescence microscope; e, TPC1 cells were infected with HMGA1/GV248RNAi-LV\#3 RNAi (KD group) at a high MOI in the optical microscope; f, TPC1 cells of KD group at a high MOI in the fluorescence microscope. Scale bar, $50 \mu \mathrm{m}$. (B) Fluorescence microscopy examination of the infection efficiencies of different lentiviral vectors in SW579 cells (magnification, x100). The panels are described as similar with that in (A). Scale bar, $50 \mu \mathrm{m}$. (C) Relative levels of HMGA1 in SW579 cells infected with different groups of lentiviral particles. Either low or high MOI, HMGA1 expression significantly decreased in SW579 cells infected with different groups of lentiviral particles. The highest knockdown efficiency was obtained using KD3 lentiviral particles. ${ }^{*} \mathrm{P}<0.05,{ }^{* *} \mathrm{P}<0.01$.

the invasion of thyroid cancer SW579 cells, we performed the transwell invasion assay and scratch-wound assay. It was shown that the invasion rate and the migration ability of SW579 cells in HMGA1 knockdown group was significantly lower than that in control and $\mathrm{NC}$ groups (Fig. 6A and B). In addition, we found that lentivirus-mediated knockdown of
HMGA1 resulted in downregulation of MMP-2, and upregulation of E-cadherin in SW579 cells (Fig. 6C).

HMGA1 correlates with MMP-2 expression in thyroid carcinoma. To further indentify the relationship between HMGA1 and MMP2 in thyroid cancer, we examined the expression 


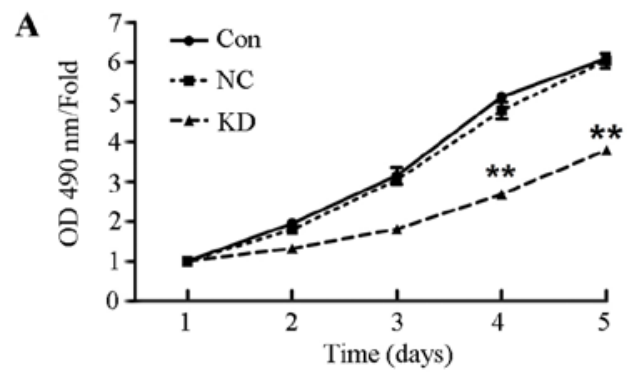

B
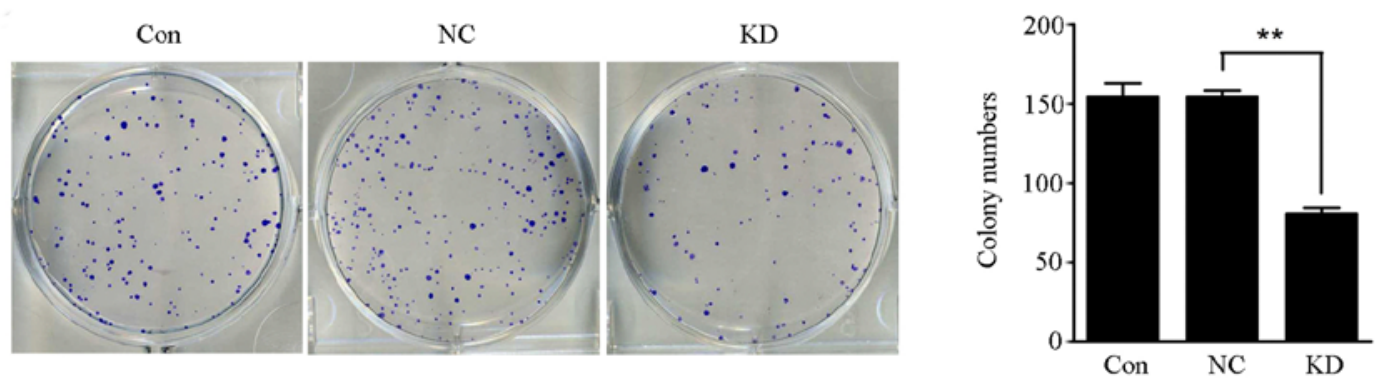

C
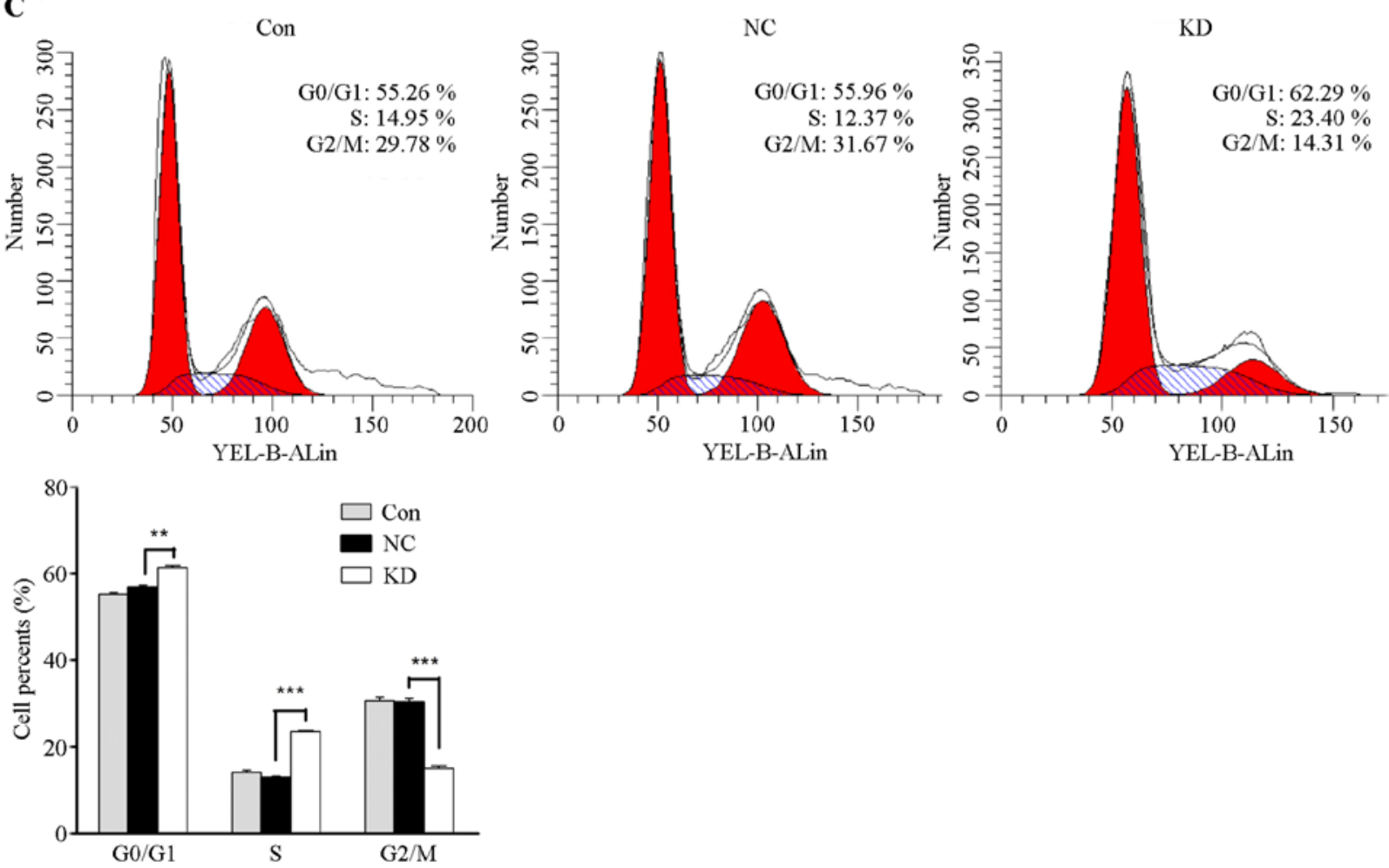

Figure 5. Lentivirus-mediated HMGA1 knockdown inhibited TPC1 cell growth. (A) MTT assay showed that lentivirus-mediated HMGA1 knockdown significantly inhibited thyroid cancer TPC1 cell proliferation $(\mathrm{n}=3) .{ }^{* * *} \mathrm{P}<0.01$. (B) Lentivirus-mediated HMGA1 knockdown significantly inhibited thyroid cancer TPC1 cell colony formation ( $\left.n=3,{ }^{* * *} P<0.01\right)$. (C) The cells in the $\mathrm{G}_{0}-\mathrm{G}_{1}$ and $\mathrm{S}$ phases significantly increased and the cells in the $\mathrm{S}$ phase significantly decreased in lentivirus-mediated HMGA1 knockdown group $\left({ }^{* * *} \mathrm{P}<0.01 ;{ }^{* * *} \mathrm{P}<0.001\right)$.

of HMGA1 and MMP2 using a tissue microarray (TH8010a, US Biomax), consisting of 70 thyroid cancer cases and 10 normal cases. The clinicopathological data are available in Table I. Statistical analysis showed that the expression of HMGA1 in thyroid carcinoma was not significantly correlated with the clinicopathological parameters of thyroid carcinoma (Table I, P>0.05). HMGA1 and MMP-2 immunostaining of thyroid carcinoma and normal tissue of representative cases are shown in Fig. 7. The immunohistochemistry analysis revealed that HMGA1 was stained in $40.0 \%$ in normal thyroid tissue and $98.6 \%$ in thyroid tumors $(\mathrm{P}<0.001$, Table II). MMP-2 expressed in $58.6 \%$ of thyroid tumors, and completely loss in normal thyroid tissue $(\mathrm{P}<0.001$, Table II). Furthermore, the expression of MMP-2 in papillary carcinoma was also significantly higher than that in follicular carcinoma and undifferentiated carcinoma (Table I, P<0.001). In addition, expression of HMGA1 and MMP-2 was found to be positively correlated in thyroid tumors (Table III, $\mathrm{r}=0.284, \mathrm{P}=0.017$ ). 
Table I. Correlation of HMGA1 and MMP-2 expression with clinicopathological parameters in thyroid cancer.

\begin{tabular}{|c|c|c|c|c|c|c|c|c|c|c|}
\hline & \multirow[b]{2}{*}{$\mathrm{n}$} & \multicolumn{3}{|c|}{ HMGA1 } & \multirow[b]{2}{*}{ P-value } & \multicolumn{4}{|c|}{ MMP-2 } & \multirow[b]{2}{*}{ P-value } \\
\hline & & - & + & ++ & & - & + & ++ & +++ & \\
\hline Age (years) & & & & & 0.469 & & & & & 0.312 \\
\hline$>50$ & 32 & 0 & 11 & 21 & & 12 & 5 & 10 & 5 & \\
\hline$\leq 50$ & 38 & 1 & 15 & 22 & & 17 & 7 & 12 & 2 & \\
\hline Gender & & & & & 0.777 & & & & & 0.113 \\
\hline Male & 14 & 0 & 5 & 9 & & 9 & 1 & 3 & 1 & \\
\hline Female & 56 & 1 & 21 & 34 & & 20 & 11 & 19 & 6 & \\
\hline Node metastasis & & & & & 0.094 & & & & & 0.725 \\
\hline Positive & 15 & 0 & 3 & 12 & & 6 & 4 & 4 & 1 & \\
\hline Negative & 55 & 1 & 23 & 31 & & 23 & 8 & 18 & 6 & \\
\hline Tumor size $(\mathrm{cm})$ & & & & & 0.940 & & & & & 0.117 \\
\hline $\mathrm{T} 2$ & 31 & 0 & 11 & 20 & & 11 & 4 & 11 & 5 & \\
\hline $\mathrm{T} 3$ & 23 & 1 & 10 & 12 & & 10 & 5 & 6 & 2 & \\
\hline $\mathrm{T} 4$ & 16 & 0 & 5 & 11 & & 8 & 3 & 5 & 0 & \\
\hline Tumor types & & & & & 0.574 & & & & & $<0.001$ \\
\hline Papillary & 44 & 1 & 14 & 29 & & 11 & 8 & 19 & 6 & \\
\hline Follicular & 20 & 0 & 11 & 9 & & 14 & 3 & 2 & 1 & \\
\hline Undifferentiated & 6 & 1 & 5 & 0 & & 4 & 1 & 1 & 0 & \\
\hline Stage & & & & & 0.589 & & & & & 0.977 \\
\hline I & 27 & 1 & 10 & 16 & & 13 & 6 & 8 & 0 & \\
\hline II & 17 & 0 & 6 & 11 & & 2 & 2 & 9 & 4 & \\
\hline III & 19 & 0 & 9 & 10 & & 10 & 2 & 4 & 3 & \\
\hline IV & 7 & 0 & 1 & 6 & & 4 & 2 & 1 & 0 & \\
\hline
\end{tabular}

Table II. Expressions of HMGA1 and MMP-2 in thyroid normal tissue and cancer.

\begin{tabular}{|c|c|c|c|c|c|c|c|}
\hline & \multirow[b]{2}{*}{$\mathrm{n}$} & \multicolumn{2}{|c|}{ HMGA1 } & \multirow[b]{2}{*}{ P-value } & \multicolumn{2}{|c|}{ MMP-2 } & \multirow[b]{2}{*}{ P-value } \\
\hline & & Positive & Negative & & Positive & Negative & \\
\hline Tissue types & & & & $<0.001$ & & & $<0.001$ \\
\hline Normal & 10 & 4 & 6 & & 0 & 10 & \\
\hline Tumor & 70 & 69 & 1 & & 41 & 29 & \\
\hline
\end{tabular}

Table III. Correlation of HMGA1 and MMP-2 expression in thyroid cancer.

\begin{tabular}{|c|c|c|c|c|c|c|}
\hline & \multirow[b]{2}{*}{$\mathrm{n}$} & \multicolumn{3}{|c|}{ HMGA1 } & \multirow[b]{2}{*}{ P-value } & \multirow[b]{2}{*}{ Spearman $(\mathrm{r})$} \\
\hline & & - & + & ++ & & \\
\hline MMP-2 & & & & & 0.017 & 0.284 \\
\hline- & 29 & 1 & 15 & 13 & & \\
\hline+ & 12 & 0 & 4 & 8 & & \\
\hline++ & 22 & 0 & 5 & 17 & & \\
\hline+++ & 7 & 0 & 2 & 5 & & \\
\hline
\end{tabular}

\section{Discussion}

HMGA1 plays a carcinogenic role in the initiation and progression of different types of tumors. HMGA1 overexpression promoted pancreatic adenocarcinoma cells Akt activation (31), and its knockdown inhibited breast cancer cell proliferation and migration of immunodeficient mice (32). HMGA1 was able to regulate basal-like breast cancer EMT, and to promote breast cancer metastasis (33). HMGA1 knockdown increased p53 levels, restore normal stem cell properties of colon cancer stem cells (34). HMGA1 is associated with poor clinical outcome in patients with uveal melanomas (35). 
A

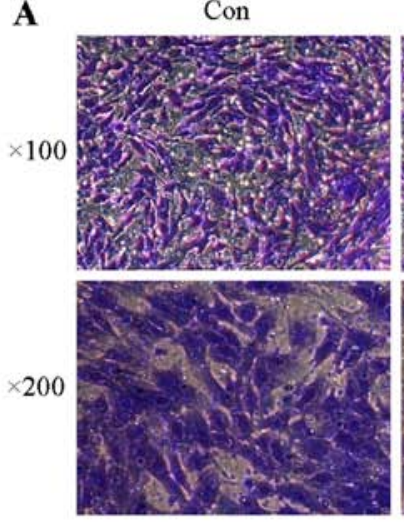

$\mathbf{B}$

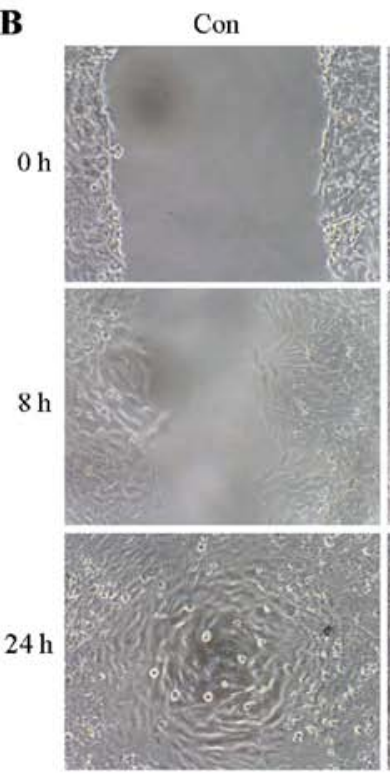

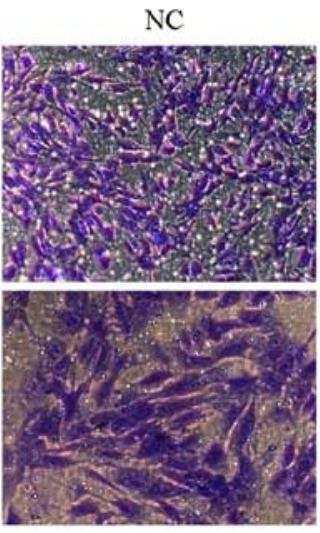

$\mathrm{NC}$

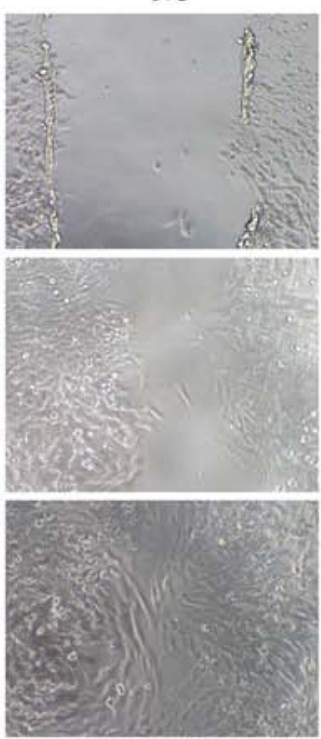

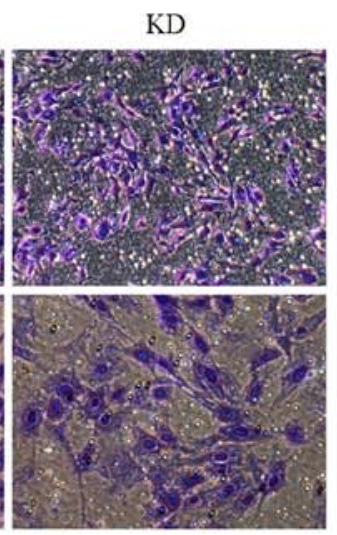

$\mathrm{KD}$

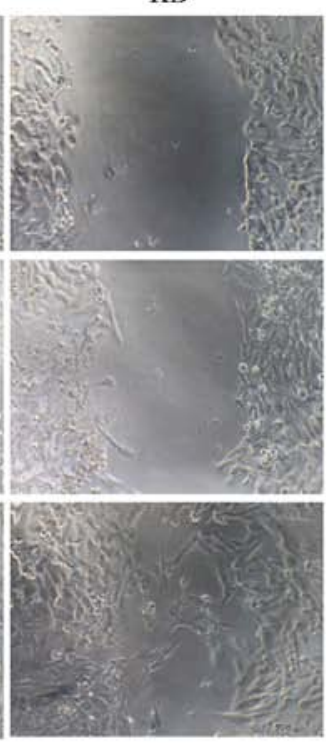

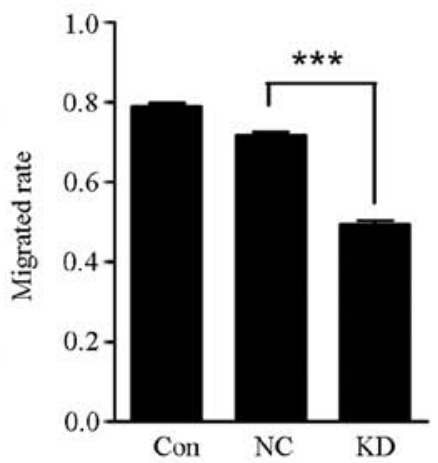
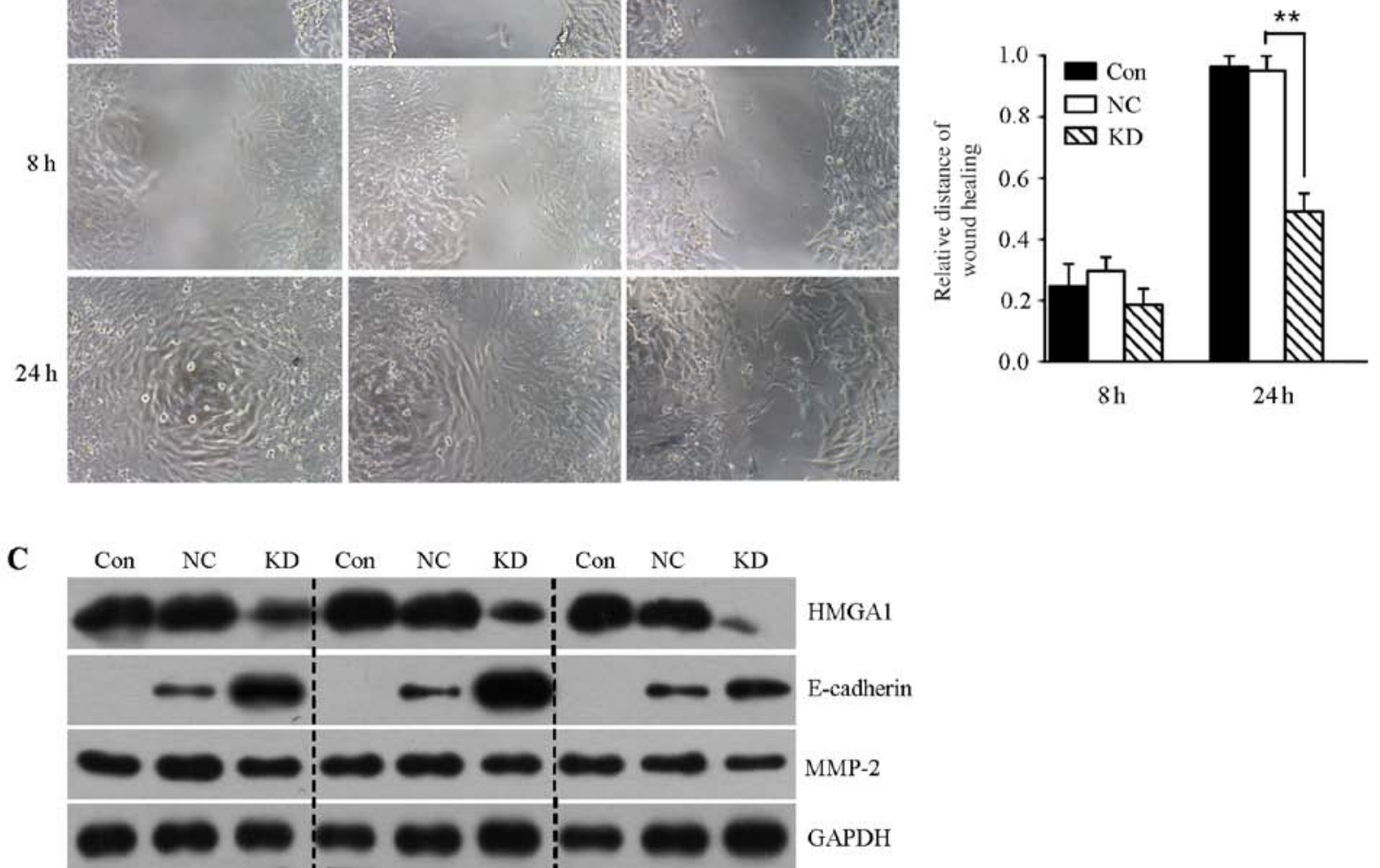

Figure 6. Lentivirus-mediated HMGA1 knockdown inhibited SW579 cell invasion and migration. (A) Lentivirus-mediated HMGA1 knockdown significantly inhibited thyroid cancer SW579 cell invasion. ${ }^{* * *} \mathrm{P}<0.001$. (B) Lentivirus-mediated HMGA1 knockdown significantly inhibited thyroid cancer SW579 cell migration, ${ }^{* *} \mathrm{P}<0.01$. (C) Western blotting assay showed that lentivirus-mediated HMGA1 knockdown decreased MMP-2 expression, and increased E-cadherin expression in SW579 cells.

TGF- $\beta 1$ is a ubiquitous cytokine exerting a necessary role in many aspects of cellular behavior, including cell proliferation, differentiation and apoptosis. TGF- $\beta 1$ is a tumor suppressor in the early phase of tumor and becomes a tumor-promoting factor during the late stages of cancer and embryonic development (15-17). This study offers evidence of association between TGF- $\beta 1$ and HMGA1 in the development of thyroid cancer, and TGF- $\beta 1$ increased the level of HMGA1 mRNA and protein in thyroid cancer SW579 cells. Since PI3K signaling and ERK signaling have previously been described as two kinds of non-Smad signaling pathways regulating the TGF- $\beta 1$ signaling pathway (19), we aimed to assess their involvements in the TGF- $\beta 1$-induced HMGA1 expression. We found that both of them participated in this process, whether PI3K signaling and ERK signaling work in parallel or direct coordination with Smad proteins in TGF- $\beta 1$-induced HMGA1 expression remains to be further clarified.

With lentivirus-mediated HMGA1 silencing, this study revealed that HMGA1 knockdown could inhibit cellular oncogenic properties of thyroid cancer cells in vitro. Furthermore, 


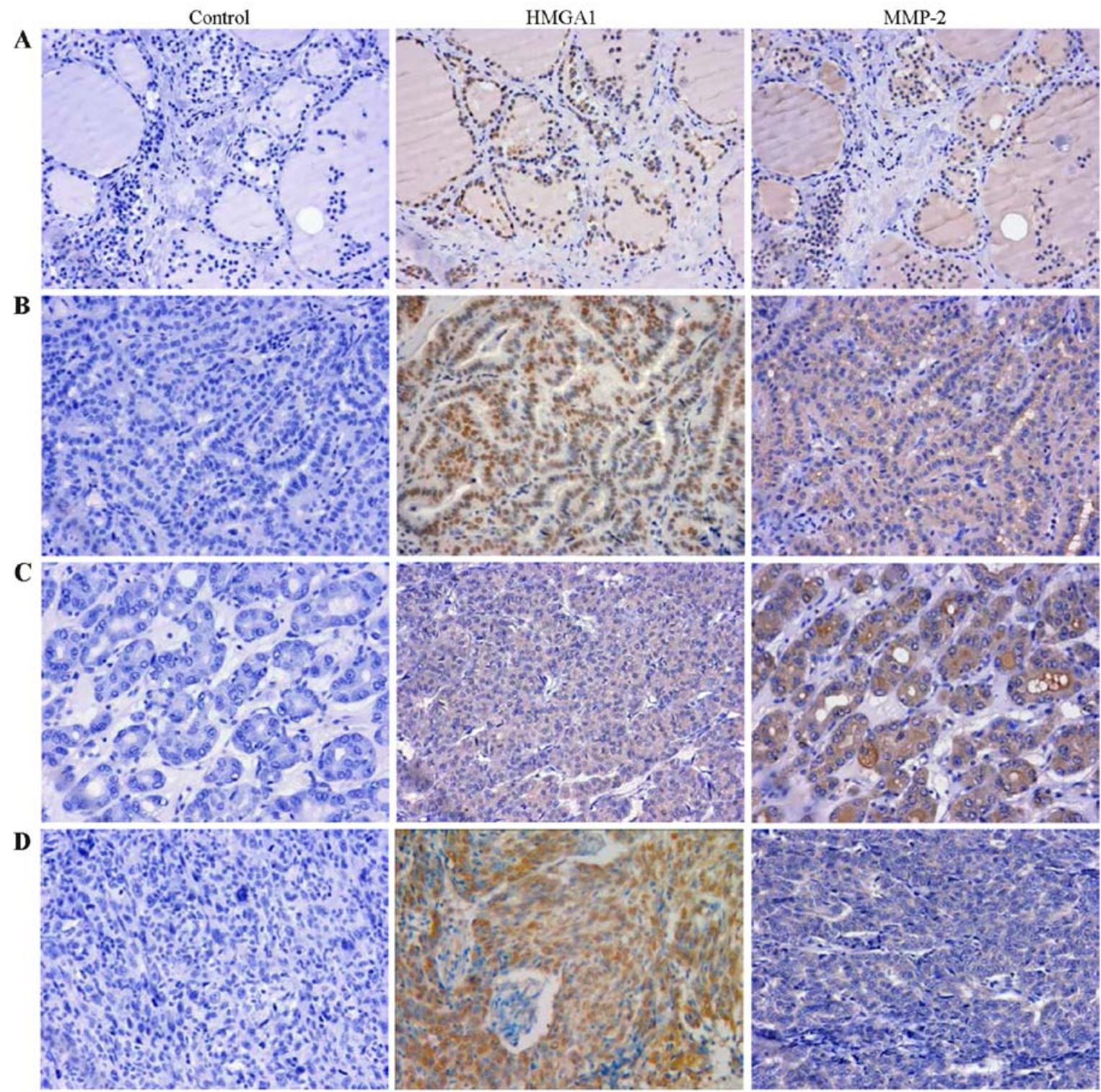

Figure 7. HMGA1 protein expression correlates with MMP-2 expression in thyroid carcinoma (images in original magnification, x400). (A) Thyroid normal tissue. (B) Thyroid papillary carcinoma. (C) Thyroid follicular carcinoma. (D) Thyroid undifferentiated carcinoma.

the lentivirus-mediated HMGA1 downregulation decreased expression of MMP-2, and increased E-cadherin expression in SW579 cells, indicating the involvement of MMP-2 and E-cadherin in HMGA1 induced cellular invasion. Our previous study also confirmed that the siRNA mediated HMGA1 knockdown can decrease Snail expression, and increase E-cadherin expression, resulting in the suppression of thyroid cancer cell growth and invasion (30). It was reported that HMGA1 overexpression could promote the DNA-damage response, and stimulate Akt activation in colon and thyroid anaplastic carcinoma (36). HMGA1 downregulation by siRNA enhanced transcriptional activity of p53, and increased thyroid cancer apoptosis (37). It was also reported that HMGA1 proteins can inhibit Hand1 promoter activity, and HMGA1 overexpression exerts an important role on HAND1 silencing in differentiated thyroid carcinomas (38). In addition, HMGA1 silencing decreased the expression of vimentin and Snail, increased the expression of E-cadherin in triple-negative breast cancer
MDA-MB-231 cells (4). Moreover, our previous study also found that TGF- $\beta 1$ could upregulate HMGA1 expression through the PI3K/Akt pathway, and HMGA1 enhanced the proliferation and migration ability in breast cancer cells (39), consistent with the results of this study. Those results suggest that HMGA1 may play a necessary role in the progress of thyroid cancer and breast cancer, and it could contribute to the understanding of the molecular basis of solid cancer progression and invasion, opening new perspectives in cancer management and precision therapy.

To further reveal the significance of HMGA1 in clinical prognosis, we used the tissue microarray to detect the expression of HMGA1 in thyroid carcinoma and normal thyroid tissues. We observed that HMGA1 was expressed in thyroid carcinoma more than that in normal thyroid tissues. However, we did not obtain data for the association of HMGA1 expression with node metastasis in this study. The expression level of MMP-2 in thyroid carcinoma was significantly higher than 
that in normal thyroid tissue. Moreover, MMP-2 expression in thyroid carcinoma is associated with the tumor types, which was not reported previously in other cancers. HMGA1 and MMP-2 are reported to be positively correlated in a subgroups of carcinosarcomas (40), and HMGA1 drives transformation through upregulation of MMP-2 in undifferentiated, large-cell carcinoma (41). HMGA1 also upregulates expression of MMP-2 in prostate cancer (42). In addition, HMGA1 promotes cellular invasiveness through PI3K/Akt-dependent regulation of MMP-9 activity in pancreatic cancer (43), and induces MMP-13 expression in breast cancer (44), indicating that HMGA1-MMP axis plays an important role in a variety of human cancers. The tissue microarray data revealed a positive correlation between MMP-2 and HMGA1 expression $(\mathrm{P}=0.017)$, which was consistent with cellular model results, suggesting that HMGA1 plays an important role in regulating MMP-2 expression in human thyroid cancer. Further clarification of underlying molecular mechanisms will help to understand the role of HMGA1 in TGF- $\beta 1$ signaling in the progress of thyroid cancer.

In conclusion, the present study established the first link between HMGA1 and TGF- $\beta 1$ in the regulation of thyroid cancer proliferation and invasion, and provides evidence for the pivotal role of HMGA1 in the progression of thyroid cancer, rending HMGA1 to be potential biological marker for the diagnosis of thyroid cancer.

\section{Acknowledgements}

This study was supported by projects from the National Natural Science Foundation of China (grant nos. 31200573, 81172542 and 81472608), the Key project of Education Department of Hunan Province (16A189), Natural Science Foundation of Hunan Province (2016JJ4077) and Young Talents Program of the University of South China.

\section{References}

1. Fusco A and Fedele M: Roles of HMGA proteins in cancer. Nat Rev Cancer 7: 899-910, 2007.

2. Reeves R: Nuclear functions of the HMG proteins. Biochim Biophys Acta 1799: 3-14, 2010.

3. Resar LM: The high mobility group A1 gene: Transforming inflammatory signals into cancer? Cancer Res 70: 436-439, 2010.

4. Shah SN, Cope L, Poh W, Belton A, Roy S, Talbot CC Jr, Sukumar S, Huso DL and Resar LM: HMGA1: A master regulator of tumor progression in triple-negative breast cancer cells. PLoS One 8: e63419, 2013.

5. Abe N, Watanabe T, Masaki T, Mori T, Sugiyama M, Uchimura H, Fujioka Y, Chiappetta G, Fusco A and Atomi Y: Pancreatic duct cell carcinomas express high levels of high mobility group I(Y) proteins. Cancer Res 60: 3117-3122, 2000.

6. Meyer B, Loeschke S, Schultze A, Weigel T, Sandkamp M, Goldmann T, Vollmer E and Bullerdiek J: HMGA2 overexpression in non-small cell lung cancer. Mol Carcinog 46: 503-511, 2007.

7. Masciullo V, Baldassarre G, Pentimalli F, Berlingieri MT, Boccia A, Chiappetta G, Palazzo J, Manfioletti G, Giancotti V, Viglietto $\mathrm{G}$, et al: HMGA1 protein over-expression is a frequent feature of epithelial ovarian carcinomas. Carcinogenesis 24: 1191-1198, 2003

8. Belton A, Gabrovsky A, Bae YK, Reeves R, IacobuzioDonahue C, Huso DL and Resar LM: HMGA1 induces intestinal polyposis in transgenic mice and drives tumor progression and stem cell properties in colon cancer cells. PLoS One 7: e30034, 2012
9. Chiappetta G, Tallini G, De Biasio MC, Manfioletti G, MartinezTello FJ, Pentimalli F, de Nigris F, Mastro A, Botti G, Fedele M, et al: Detection of high mobility group I HMGI(Y) protein in the diagnosis of thyroid tumors: HMGI(Y) expression represents a potential diagnostic indicator of carcinoma. Cancer Res 58: 4193-4198, 1998.

10. Huang R, Huang D, Dai W and Yang F: Overexpression of HMGA1 correlates with the malignant status and prognosis of breast cancer. Mol Cell Biochem 404: 251-257, 2015.

11. Heldin $\mathrm{CH}$, Landström $\mathrm{M}$ and Moustakas A: Mechanism of TGF-beta signaling to growth arrest, apoptosis, and epithelialmesenchymal transition. Curr Opin Cell Biol 21: 166-176, 2009.

12. Ikushima $\mathrm{H}$ and Miyazono K: TGFbeta signalling: A complex web in cancer progression. Nat Rev Cancer 10: 415-424, 2010.

13. Massagué J: TGFbeta in cancer. Cell 134: 215-230, 2008.

14. Yang L, Pang Y and Moses HL: TGF-beta and immune cells: An important regulatory axis in the tumor microenvironment and progression. Trends Immunol 31: 220-227, 2010.

15. Inman GJ: Switching TGF $\beta$ from a tumor suppressor to a tumor promoter. Curr Opin Genet Dev 21: 93-99, 2011.

16. Joshi A and Cao D: TGF-beta signaling, tumor microenvironment and tumor progression: The butterfly effect. Front Biosci (Landmark Ed) 15: 180-194, 2010.

17. Meulmeester E and Ten Dijke P: The dynamic roles of TGF- $\beta$ in cancer. J Pathol 223: 205-218, 2011.

18. Smith AL, Robin TP and Ford HL: Molecular pathways: Targeting the TGF- $\beta$ pathway for cancer therapy. Clin Cancer Res 18: 4514-4521, 2012.

19. Derynck R, Akhurst RJ and Balmain A: TGF-beta signaling in tumor suppression and cancer progression. Nat Genet 29: 117-129, 2001.

20. Lenferink AE, Cantin C, Nantel A, Wang E, Durocher Y, Banville M, Paul-Roc B, Marcil A, Wilson MR and O'ConnorMcCourt MD: Transcriptome profiling of a TGF-beta-induced epithelial-to-mesenchymal transition reveals extracellular clusterin as a target for therapeutic antibodies. Oncogene 29: 831-844, 2010.

21. Vincent T, Neve EP, Johnson JR, Kukalev A, Rojo F, Albanell J, Pietras K, Virtanen I, Philipson L, Leopold PL, et al: A SNAIL1SMAD3/4 transcriptional repressor complex promotes TGF-beta mediated epithelial-mesenchymal transition. Nat Cell Biol 11: 943-950, 2009.

22. Voulgari A and Pintzas A: Epithelial-mesenchymal transition in cancer metastasis: Mechanisms, markers and strategies to overcome drug resistance in the clinic. Biochim Biophys Acta 1796: 75-90, 2009.

23. Wendt MK, Allington TM and Schiemann WP: Mechanisms of the epithelial-mesenchymal transition by TGF-beta. Future Oncol 5: 1145-1168, 2009.

24. Zhong J, Cao RX, Zu XY, Hong T, Yang J, Liu L, Xiao XH, Ding WJ, Zhao Q, Liu JH, et al: Identification and characterization of novel spliced variants of PRMT2 in breast carcinoma. FEBS J 279: 316-335, 2012.

25. Lois C, Hong EJ, Pease S, Brown EJ and Baltimore D: Germline transmission and tissue-specific expression of transgenes delivered by lentiviral vectors. Science 295: 868-872, 2002.

26. Zhong J, Cao RX, Liu JH, Liu YB, Wang J, Liu LP, Chen YJ, Yang J, Zhang QH, Wu Y, et al: Nuclear loss of protein arginine $\mathrm{N}$-methyltransferase 2 in breast carcinoma is associated with tumor grade and overexpression of cyclin D1 protein. Oncogene 33: 5546-5558, 2014

27. Welch DR, Fabra A and Nakajima M: Transforming growth factor beta stimulates mammary adenocarcinoma cell invasion and metastatic potential. Proc Natl Acad Sci USA 87: 7678-7682, 1990.

28. Derynck R and Zhang YE: Smad-dependent and Smadindependent pathways in TGF-beta family signalling. Nature 425: 577-584, 2003.

29. Moustakas A and Heldin CH: Non-Smad TGF-beta signals. J Cell Sci 118: 3573-3584, 2005.

30. Zhong J, Liu C, Chen YJ, Zhang QH, Yang J, Kang X, Chen SR, Wen GB, Zu XY and Cao RX: The association between S100A13 and HMGA 1 in the modulation of thyroid cancer proliferation and invasion. J Transl Med 14: 80, 2016.

31. Liau SS, Jazag A, Ito K and Whang EE: Overexpression of HMGA1 promotes anoikis resistance and constitutive Akt activation in pancreatic adenocarcinoma cells. Br J Cancer 96: 993-1000, 2007.

32. Di Cello F, Shin J, Harbom K and Brayton C: Knockdown of HMGA1 inhibits human breast cancer cell growth and metastasis in immunodeficient mice. Biochem Biophys Res Commun 434: 70-74, 2013 
33. Pegoraro S, Ros G, Piazza S, Sommaggio R, Ciani Y, Rosato A Sgarra R, Del Sal G and Manfioletti G: HMGA1 promotes metastatic processes in basal-like breast cancer regulating EMT and stemness. Oncotarget 4: 1293-1308, 2013.

34. Puca F, Colamaio M, Federico A, Gemei M, Tosti N, Bastos AU, Del Vecchio L, Pece S, Battista S and Fusco A: HMGA1 silencing restores normal stem cell characteristics in colon cancer stem cells by increasing p53 levels. Oncotarget 5: 3234-3245, 2014.

35. Qu Y, Wang Y, Ma J, Zhang Y, Meng N, Li H, Wang Y and Wei W: Overexpression of high mobility group A1 protein in human uveal melanomas: Implication for prognosis. PLoS One 8: e68724, 2013

36. D'Angelo D, Mussnich P, Rosa R, Bianco R, Tortora G and Fusco A: High mobility group A1 protein expression reduces the sensitivity of colon and thyroid cancer cells to antineoplastic drugs. BMC Cancer 14: 851, 2014.

37. Frasca F, Rustighi A, Malaguarnera R, Altamura S, Vigneri P, Del Sal G, Giancotti V, Pezzino V, Vigneri R and Manfioletti G: HMGA1 inhibits the function of p53 family members in thyroid cancer cells. Cancer Res 66: 2980-2989, 2006.

38. Martinez Hoyos J, Ferraro A, Sacchetti S, Keller S, De Martino I, Borbone E, Pallante P, Fedele M, Montanaro D, Esposito F, et al: HAND1 gene expression is negatively regulated by the High Mobility Group A1 proteins and is drastically reduced in human thyroid carcinomas. Oncogene 28: 876-885, 2009.
39. Zu X, Zhong J, Tan J, Tan L, Yang D, Zhang Q, Ding W, Liu W, Wen $\mathrm{G}$, Liu J, et al: TGF- $\beta 1$ induces HMGA1 expression in human breast cancer cells: Implications of the involvement of HMGA1 in TGF- $\beta$ signaling. Int J Mol Med 35: 693-701, 2015.

40. Hillion J, Roy S, Heydarian M, Cope L, Xian L, Koo M, Luo LZ, Kellyn K, Ronnett BM, Huso T, et al: The high mobility group A1 (HMGA1) gene is highly overexpressed in human uterine serous carcinomas and carcinosarcomas and drives matrix metalloproteinase-2 (MMP-2) in a subset of tumors. Gynecol Oncol 141: 580-587, 2016.

41. Hillion J, Wood LJ, Mukherjee M, Bhattacharya R, Di Cello F, Kowalski J, Elbahloul O, Segal J, Poirier J, Rudin CM, et al: Upregulation of MMP-2 by HMGA1 promotes transformation in undifferentiated, large-cell lung cancer. Mol Cancer Res 7: 1803-1812, 2009.

42. Takaha N, Resar LM, Vindivich D and Coffey DS: High mobility group protein HMGI(Y) enhances tumor cell growth, invasion, and matrix metalloproteinase-2 expression in prostate cancer cells. Prostate 60: 160-167, 2004.

43. Liau SS, Jazag A and Whang EE: HMGA1 is a determinant of cellular invasiveness and in vivo metastatic potential in pancreatic adenocarcinoma. Cancer Res 66: 11613-11622, 2006.

44. Reeves R, Edberg DD and Li Y: Architectural transcription factor HMGI(Y) promotes tumor progression and mesenchymal transition of human epithelial cells. Mol Cell Biol 21: 575-594, 2001. 